\title{
The Strategy of Development of the Various Efforts of Forestry at the Association of Community Forest Tandung Billa in West Wara District Palopo City
}

\author{
Imelda $^{* 1}$, Syamsuddin Millang ${ }^{1}$, Siti Nuraeni ${ }^{1}$ \\ *Faculty of Forestry, Hasanuddin University, St. PerintisKemerdekaan Km. 10 Tamalanrea, Makassar, \\ South Sulawesi, Indonesia
}

\begin{abstract}
.
The development of commodity a variety of forestry business is not done with how to remodel a forest but rather seek the optimization of the plants growing through the improvement of the structure and composition of the forest. Program social forestry opens the opportunity for the community around the forest to ask the government for the proper management of the forest area. One form of Social Forestry is a Community Forest (Community forest) implemented in a Permit for Utilization of Community Forest (IUPCommunity forest). This study aims to analyze the internal and external factors that determine the success of managing a Variety of Forestry businesses in Forest farmer groupCommunity forestTandungBilla then formulate a strategy for the development of Various Businesses of the forester. Data collection methods using is interview techniques, direct observation, and literature study. Data analysis was done by descriptive qualitative, followed by the SWOT analysis method, i.e., assessment of the internal factors includes strengths and weaknesses, and external factors have factors opportunities and threats. The results showed that various Forestry Business development strategies in Forest farmer groupCommunity forestTandungBilla are located in quadrant I (one), which means it has an Aggressive Strategy (Positive - Positive). The Total Value of the IFAS, namely 2,03, is greater than the total value of the EFAS that is 1,71. Thus, the various efforts of forestry make it possible to continue to perform the activities of management, development, and increment the results of the production of non-Timber Forest products in Forest farmer groupCommunity forestTandungBilla in West WaraDistrict of the City of Palopo.
\end{abstract}

Keywords: Business of Forestry; the Forest Society's; Joint Forest Farmers Group

\section{INTRODUCTION}

The pattern of utilization of land with a variety of the forestry business (AUK) is one of the alternative efforts to optimize the space to grow with the developing a range of commodities - timber forest-yang has the potential value of high economic. The development of the AUK directed on the item the results of non-timber forest products (NTFPS) with the pattern of agroforestry, as well as various types of plant income fruit and sap, the plant producing essential oils, and the forest reserves of food[1]

The development of commodity a variety of forestry businesses can be done in various forest areas (production, protection, conservation, and owned forests). The development of entity a type of forestry business is done not by changing the forest but instead seeking the optimization of the plant to grow through the improvement of the structure and composition of the forest [2]. Members Forest farmer groupTandungBilla in Battang Village City of Palopo applyagrosilvilculture to make the forest trees a standing plant for their crops. Like vanilla plants by utilizing a tree as standing or planting pepper on the sidelines of the forest stands and seasonal plants. Like coffee, mangosteen, durian, also mango as the shade of the [3].

The village Battang is located in upstream of the City in the Province and is the 'lungs' of the City of Palopo. If the site of the forest in the Village of Battang is broken, it will result in flooding and landslides in the City of Palopo and the surrounding area. However, the reserved forest area in the Village of Battang has a natural potential that quite many people for Battang village and the surrounding area. Brazilian protect the forest in this area gives a lot of advantages for the local community and even become a source of livelihood for the local population. This area also provides non-Timber Forest products (NTFPS) such as a palm tree that used the local 
community to produce sugar-palm sugar, honey cultivation and Apis dorsata, fruits such as durians, rambutans, and MP dsatts, rattan, and other plants (plant medicines) are used to increase revenue and plant drugs for Lang. Thus, the pattern of land use with the commodities of the various efforts of Forestry (AUK) is very potential to be developed in an area that the majority of the population around them is highly dependent on the forest in the forest area belongs to the land has not yet been reached in the Optimize[3].

The development of commodity a variety of forestry businesses (AUK) can reduce the pressure of society on the forest either in the form of forest encroachment and illegal logging; it can also increase the community's income significantly and at the same time rehabilitate degraded land. A commodity that was developed is a leading commodity in the local according to the conditions of the biophysical region, mastery of technology and culture people local [4].

Forestry social Program provides an opportunity for the community around the forest to ask the government for the proper management of the forest area. The public can submit management rights over the location identified in the Indicative Access Forest Governance Social [5]. Permission for Utilization of Community Forest (IUPCommunity forest) Forest farmer grouphutTandungBilla according to the DECREE of the Minister of environment and forestry Number: SK. 252/MsLHK-PSKVPKPS/PSL.o/512017 May 8, 2017, of 1.617 ha. Forest farmer grouphutTandungBilla consists of five forest farmer group (KTH), namely KTH Tongkon, KTH Tombarani, KTH Mappatongko, KTH Kalibambang and KTH TandungBilla[6]. As a form of the application program,the work plan of business (RKU) and annual work plan (CTR) has been prepared by Forest farmer grouphutTandungBillafor ten years, then formed a Group of Business Social Forestry (KUPS). KUPS is made to facilitate the program's implementation for the welfare of the Forest farmer grouphutTandungBilla by not ignoring the principle of the preservation of the forest. There are three models of the development of the economic potential are pursued by Forest farmer groupTandungBilla, namely: agroforestry, the utilization of non-wood forest products, and environmental services.

\section{The Purpose Of The Study}

1. Analyze the factors internal and external that determine the success of the management of a Variety of Forestry businesses in Forest farmer groupCommunity forestTandungBilla

2. Formulate a strategy for the development of a Variety of Forestry businesses in Forest farmer groupCommunity forestTandungBilla.

\section{RESEARCH METHODS}

\section{A. Location and Time of Research}

The research was conducted in the TandungBilla Community Forest, Battang Village, WestWara District of Palopo City in October - December 2020. This research was conducted on the 9 (the nine) Business Group Social Forestry, namely: 1) KUPS Silvofishery Stone Tongkon, 2) KUPS AgrosilvopasturaTombang, 3) KUPS AgrisilvikulturTambunTana, 4) KUPS Farm Kalibambang, 5) KUPS AgrosilvofisheryKalang Gum, 6) KUPS ApicultureLambanan, 7) KUPS Bamba Butterfly, 8) KUPS Rattan Tirowali, 9) KUPS Nursery Forest Plants and BatuTanan MPTs.

\section{B. Tools and Materials}

The tool used in this research is stationery, camera, questionnaires, and computer. The object of this research is a member of the Association of Community Forest TandungBilla.

\section{Data Type \\ a. Primary Data}

Primary Data is data obtained directly from respondents and direct observation in the field; the question that is collected through the activities is as follows :

(1) The observation that primary data collection conducted with how to hold a direct statement of the condition seems to exist as the object of research in the field. 
(2) The interview is the process of obtaining information for research through question and answer face-to-face between the interviewer and the informant, using the questionnaire or not.

(3) Documentation is by doing shooting in the field through the photoshoot to support the visualization of data that have been obtained earlier through the techniques of collecting data.

\section{b. Secondary Data}

Secondary data was taken to complement and support the primary data. Data were obtained from relevant Government agencies, the office of Headman Battang, District Office, Bar the West and the literature pertinent to this study such as :

1. The regulations and Policies related to Community Forest

2. Data about the Community Forest

3. The general state of the research area

\section{How To Data Collection}

Data collection was done by interview and literature study. The interview was conducted as an attempt to obtain primary data. Literature is the secondary data collection method by reading and citing the theories from books and other writings relevant to the research.

\section{E. Population and Sample}

The population in this research is the community around the forest in the Village BattangWest Wara District and related agencies. While the sampling was done by purposive sampling with consideration that the respondent selected is an individual with the criteria of representatives of Forest Farmers group, which consists of each of the chairman of the KUPS 9 (nine) persons, members of the KUPS each 2 (two) and Chairman of the Association of Community forestTandungBilla. Then for the retrieval of the respondents in the environment agencies associated with some members of the population related to the research purposes, respondents who selected the Head KPH Latimojong and Forestry Extension that accompany the activities of the Community Forest TandungBilla.

\section{F. Techniques Of Data Analysis}

\section{Qualitative Descriptive Analysis}

Data on the types of various forestry businesses that have been obtained were analyzed descriptively to get a clear picture of the problem under study for a variety of forestry businesses Association of Community Forest TandungBilla.

\section{SWOT analysis}

The process of preparing a SWOT is made with three stages, namely:

a. The stages of data collection include primary data and secondary data

b. Stages of analysis

c. The stages of decision-making.

SWOT analyzes an organization's internal and external conditions that will subsequently be used as the basis for designing the strategy and work program. The internal analysis includes assessing the factors of force (Strength) and weakness (Weakness). Meanwhile, the external analysis includes factors opportunities (Opportunity) and a challenge (Threats). Before compiling a SWOT matrix,we will need first to collect a matrix of Factor Strategies External EFAS (external strategic factors analysis summary) and matrix Factors Internal Strategy IFAS (internal strategic factors analysis summary). The definition of EFAS is to formulate the factors an external strategy in the framework of Opportunity and Threat. Understanding IFAS is to developinternal design aspects in the framework's strengths and weaknesses[7]. The factors that will be analyzedare divided into two parts, namely internal and external elements, then create a SWOT matrix to display the eight quadrants. Two very top is the quadrant of external factors, for example, the opportunities and challenges. At the same time, the two quadrants on the left is the internal factors such as strengths and weaknesses. Four quadrant is quadrant strategic issues that arise due to the meeting point between the internal factors and external[6]. Based on the SWOT matrix, four alternative strategies were obtained to develop the various efforts of the forestry Association of Community Forest TandungBilla in Wara West District of PalopoCity. 


\section{RESULTS AND DISCUSSION}

\section{A. The Activities Of The Association Of Community Forest TandungBilla}

The program can see the government's efforts to welfare the community around the forest of Social Forestry. One form of the program of Social Forestry is a Forest Community. Some forest farmer groups are incorporated in Forest farmer groupCommunity forestTandungBilla, located in the Village BattangWara West District ofPalopo city, empowering group members to manage and develop of various forestry businesses concerning the environmental conditions. To facilitate the implementation of the work program,Forest farmer groupCommunity forestTandungBilla established the Business Group Social Forestry (KUPS), which consists of 9 (nine) KUPS following the concentration field of KTH are there. The activities of the management and utilization of non-Timber Forest products which KUPS Forest farmer groupCommunity forestTandungBilla does can be seen in Table 1 .

Table 1. Activity Management KUPS Forest farmer groupCommunity forestTandungBilla

\begin{tabular}{|c|c|c|c|}
\hline No & Name KUPS & Types of Activities & Produk / Services produced \\
\hline 1 & SilvofisheryBatuTongkon & $\begin{array}{l}\text { The Management of the } \\
\text { cultivation of carp and tilapia } \\
\text { with plants horticultural fruit and } \\
\text { vegetable }\end{array}$ & $\begin{array}{l}\text { Obtain the result of fishing (carp } \\
\text { and tilapia) is good enough with the } \\
\text { cheap cost of maintenance and easy }\end{array}$ \\
\hline 2 & AgrosilvopasturaTombang & $\begin{array}{l}\text { Management of crops, fodder } \\
\text { (grass), and a tree }\end{array}$ & $\begin{array}{l}\text { Producing agricultural and forestry } \\
\text { simultaneously and raise farm } \\
\text { animals such as cows and goats }\end{array}$ \\
\hline 3 & AgrisilvikulturTambunTana & $\begin{array}{l}\text { Planting vanilla with the use of } \\
\text { plants of forestry, as standing } \\
\text { like tree mangosteen and durian }\end{array}$ & $\begin{array}{l}\text { Producing agricultural products } \\
\text { (vanilla and pepper) seta forest } \\
\text { crops such as mangosteen, durian } \\
\text { and mango. }\end{array}$ \\
\hline 4 & Farm Kaliba & $\begin{array}{l}\text { Management } \\
\text { environmental }\end{array}$ & $\begin{array}{l}\text { Management environmental } \\
\text { services impact on the } \\
\text { sustainability of the ecosystem of } \\
\text { the forest area and as a place of } \\
\text { both }\end{array}$ \\
\hline 5 & AgrosilvofhiseryKalangGusi & $\begin{array}{l}\text { freshwater fish farming by } \\
\text { utilizing the flow of the river } \\
\text { which is combined with coffee } \\
\text { plants, suren and mahogany }\end{array}$ & $\begin{array}{l}\text { Obtain the results of the fisheries } \\
\text { and forestry plants, such as coffee, } \\
\text { suren and mahogany }\end{array}$ \\
\hline 6 & Apiculture Lal & the Cultivation of honey bees & $\begin{array}{l}\text { Produce honey type Trigona, Sp } \\
\text { and Apisdorsata }\end{array}$ \\
\hline 7 & Bamba Butterfly & Cultivation Butterfly & $\begin{array}{l}\text { Boost butterfly populations and } \\
\text { breeding butterflies can be a place } \\
\text { both }\end{array}$ \\
\hline 8 & Rattan Tirowali & $\begin{array}{l}\text { the Processing of rattan and } \\
\text { bamboo }\end{array}$ & $\begin{array}{l}\text { Produces handicrafts made of rattan } \\
\text { and bamboo }\end{array}$ \\
\hline 9 & $\begin{array}{l}\text { Nursery Forest Plants and } \\
\text { MPTs BatuTanan }\end{array}$ & $\begin{array}{l}\text { Plant Nursery forestry and plant } \\
\text { MPTs }\end{array}$ & $\begin{array}{l}\text { Produce seeds of forest plants and } \\
\text { plant MPTs quality bleak durian } \\
\text { seeds, asparagus, avocado, agathis, } \\
\text { suren, mahogany and agarwood }\end{array}$ \\
\hline
\end{tabular}

The approach of agroforestryas a land management technology that combines plants, forestry crops, livestock, and fish can benefit economically and assist soil and water conservation activities.Some of the subsystems of agroforestry applied by KUPS in Table 1 are silvofishery, agrosilvopastura, agrisilvicultureagrosilvofhisery, and apiculture. Subsystemagroforestry plays an essential role in soil and water conservation, such as reducing the rate of erosion of the surface flow and sedimentation, maintaining soil fertility, improve soil physical properties, chemical and biological soil [8]. To overcome the danger of the erosion of the necessary conservation measures ground, such as how to strip vegetative, the slope of the land, shortened the length of the hill, and the system farm of the hallway. As for the increase, the fertility of the land 
required the addmaterial input a biological fertilizer in the form of mycorrhizae, rhizobium, and fertilized organic (fertilizes, enclosure, compost, green manure)[9]

The region's nature and environmental services, which KUPS Farm Kalibambang manages in Forest farmer groupCommunity forestTandungBilla, are divided into 2 (two) spots: spot the camping ground and path tracking well as spot the waterfall into the natural habitat of the butterflies. The Habitat of the butterfly is incorporated into the core block because the butterfly's habitat, which KUPS Bamba Butterfly manages, needs to be protected from damage and the intervention of human activity.

Commodity honey forest types of Apisdorsataand Trigonaspare commodities used by people both inside and outside forest areas in the area of Forest farmer groupCommunity forestTandungBilla. Products forest honey is sold directly to the consumer either for food or for pharmaceutical benefit. As for the scale of the industry, it has yet to be filled by yet adaa guarantee of the continuity of production from the farmers bees.Non-timber forest products such as rattan, bamboo, and palm used by the society for the fulfillment of needs are limited. Rattan and bamboo are managed by KUPS TirowaliForest farmer groupCommunity forestTandungBilla. Processing activities crafts made of rattan, such as chairs, tables, home furnishings, chicken cage, etc. While the bamboo plant is widely used for construction and building materials home semi-permanent. Yet much-developing industry craft which is made from raw bamboo[10]

Plant MPTs is a plant that can produce good money from wood or fruit. Different types of woody plants only utilize wood. Nursery Forest Plants and MPTs Stone tânan is KUPS who manage nursery crops can help the economy members of farmer groups TandungBilla. Tanaman seedlings are produced at planting by members of farmer groups TandungBilla in the area of IUP Community Forest. There are also several communities on sale for the rehabilitation of the land.

Type-types plant MPTs in an area areusually more purple in some ways than the type of plant wood with the benefits of a single good kind of endemic and exotic. These advantages, among others, come from the original habitat, have been tested and able to adapt to the environment, are worth preserving biodiversity biological, and financial worth economies and preferred by people[11].Almost all of the forest area has a diverse range of forest products in both wood and non-wood. The biodiversity of the forest ecosystem enables the growth of various types of vegetation in it. I haven't done a lot of utilization of non-timber forest products; if utilized was still limited to day-to-day needs. The management of non-timber forest products (NTFPS) is still minimal for the fulfillment of the industry's requirements. However, the development of NTFPS this availability is naturally quite promising[12].

According to [13], the potential of land resources are available with power adaptation is a natural for this type of plant non-timber forest products can be developed with a model approach based agroforestry NTFPS which is a breakthrough alternative in the utilization of a unit of land intensively to improve the productivity and quality of products so that can enhance the diversification of rural income.

\section{B. The identification of Internal and External Factors of Various Forestry Business}

The strategy of developing various forestry businesses, which is managed by the Association of Community forestTandungBilla, is directed using SWOT analysis. Before composing the analysis SWOT matrix first performed the preparation of the Internal Factors Analysis Summary (IFAS), namely internal factors strength (strength) and weakness (weakness) and External Factors Analysis Summary (EFAS), namely external factors opportunities (opportunity) and a challenge (treat). After that, calculate the value of strength, weaknesses, opportunities, and threats, then formulate a strategy for developing various forestry businesses in Forest farmer groupCommunity forestTandungBilla. To determine the strategic issues of developing a type of forestry business,Forest farmer groupCommunity forestTandungBilla can be seen on Tabel 2. 
Table 2. SWOT analysis Internal Factors Analysis Summary (IFAS)

\begin{tabular}{|c|c|c|c|c|}
\hline \multirow{2}{*}{ No } & Factors Internal Strategy & Weight & Rating & Weight X \\
\hline & (Internal Faktors) & (Weight) & (Score) & Rating \\
\hline & Sthrennght (S) & & & \\
\hline 1 & $\begin{array}{l}\text { Products NTFPS become a source of livelihood for the members of the } \\
\text { Association of Community forestTandungBilla }\end{array}$ & 0,09 & 4 & 0,37 \\
\hline 2 & $\begin{array}{l}\text { product Quality NTFPS Forest farmer groupCommunity } \\
\text { forestTandungBilla assured }\end{array}$ & 0,06 & 3 & 0,18 \\
\hline 3 & $\begin{array}{l}\text { Products-the products offered by the Association of Community } \\
\text { forestTandung is. but care less. }\end{array}$ & 0,09 & 4 & 0,37 \\
\hline 4 & rates affordable by all people & of 0.09 & 4 & 0,37 \\
\hline 5 & $\begin{array}{l}\text { Gives the economic impact that was good enough for members of the } \\
\text { KTH TandungBilla }\end{array}$ & 0,06 & 3 & 0,18 \\
\hline 6 & the Results of production can be sold retail and wholesale & of 0.09 & 4 & 0,37 \\
\hline 7 & $\begin{array}{l}\text { the Development of the forestry business with a pattern of Agroforestry } \\
\text { effect with yields }\end{array}$ & of 0.09 & 4 & 0,37 \\
\hline \multirow[t]{3}{*}{8} & $\begin{array}{l}\text { Development AUK by utilizing NTFPS have an impact on the } \\
\text { sustainability of forest ecosystems }\end{array}$ & 0,09 & 4 & 0,37 \\
\hline & Total (S) & To 0.68 & & 2,58 \\
\hline & Weaknes $(W)$ & & & \\
\hline 1 & $\begin{array}{l}\text { The Government of the City of Palopo less support program activities } \\
\text { Community forestTandungBilla }\end{array}$ & Is 0.03 & 1 & 0.06 To \\
\hline 2 & Tto develop a variety of forestry business requires a considerable cost & to 0.06 & 1 & 0.12 to \\
\hline 3 & Systems management / bookkeeping is not well-organized & 0,05 & 2 & 0,09 \\
\hline 4 & The Mastery of technology management, the result is still low & 0,06 & 2 & 0,12 \\
\hline 5 & Promotion for product-the resulting product is still less reach consumers & 0,06 & 2 & 0,18 \\
\hline \multirow[t]{3}{*}{6} & Outlets or branch to market the products of the production is still less & 0,06 & 2 & 0,18 \\
\hline & Total $(W)$ & $\mathbf{0 , 3 2}$ & & $\mathbf{0 , 5 5}$ \\
\hline & Total $(S-W)$ & 1,0 & & $2, \mathbf{0 3}$ \\
\hline
\end{tabular}

Table 2, the matrix Internal Factor Analysis Summary (IFAS) non-Timber Forest products in Forest farmer groupCommunity forestTandungBilla can be in the know that the strength of the Internal factor (power) of the result of the multiplication of the weight $\mathrm{x}$ rating is 2,58 and factors weaknesses (weakness) is 0.55 . So the total strength minus weakness $(\mathrm{S}-\mathrm{W})$ is 2,03 . If seen from the comparison of the internal factors of a higher power value than the value of the liability of it, it can be seen that the involvement of the community or members of farmer groups in Forest farmer groupCommunity forestTandungBilla in the management and utilization of nontimber forest products is significant and can help from the economic aspect. Without damaging the forest, the community or a group of farmers can acquire the advantages of non-timber forest products. In addition to the livelihoods and improving business results, the development of the potential of NTFPS can also impact the sustainability of forest ecosystems.

One of the problems faced by Forest farmer groupCommunity forestTandungBilla in developing the business of NTFPS is a substantial cost. However, the current Forest farmer groupCommunity forestTandungBilla has got help fund the financing of BLUKLHK, which is now renamed to AGENCY, and build cooperation with BRI CabangPalopo in access to capital KUPS through a loan the funds KUR. But aid funds can only be distributed to several KUPS between KUPS Apiculture Lambanan, KUPS Bamba Butterfly, and KUPS Farm Kalibambang.

In addition to the problems of the budget is large enough, the Government of the City of Palopo also less support program activities Community forestTandungBilla. This is because the tenure conflicts experienced by the community Battang by most of the group want the protected forests in the region Battang Village used as Indigenous Forest. But Forest farmer grouphutTandungBilla fixed proposes to hold a Program of Social Forestry. But the Government of the City of Palopo does not permit the Program proposal Community forest such. 
After analyzing the internal factors (IFAS), further exploring the external factors' opportunities and threats (EFAS). To know the issues of strategic development of AUK in Forest farmer groupCommunity forestTandungBilla can be seen in the table the process of SWOT Analysis is below this :

Table 3. Analysis SWOT External Factor Analysis Summary (EFAS)

\begin{tabular}{|c|c|c|c|c|}
\hline No & $\begin{array}{c}\text { Factors Strategy External } \\
\text { (EksnternalFaktors) }\end{array}$ & $\begin{array}{l}\text { Weight } \\
\text { (Weight) }\end{array}$ & $\begin{array}{l}\text { Rating } \\
\text { (Score) }\end{array}$ & $\begin{array}{l}\text { Weight } X \\
\text { the } \\
\text { Rating of } \\
\text { the }\end{array}$ \\
\hline & Opportunities $(\mathrm{O})$ & & & \\
\hline 1 & $\begin{array}{l}\text { Many of the members of the Association of TandungBilla who has an } \\
\text { interest to develop AUK }\end{array}$ & 0,09 & 3 & 0,28 \\
\hline 2 & Establish good cooperation with our business partners & to 0.09 & 4 & 0,37 \\
\hline 3 & Expand the market share to market the products of the production & of 0.09 & 4 & 0,37 \\
\hline 4 & $\begin{array}{l}\text { Members of the KTH TandungBilla've been following the } \\
\text { training/training on the management of NTFPS }\end{array}$ & 0,08 & 3 & 0,23 \\
\hline 5 & $\begin{array}{l}\text { Tools that are used to produce crop yields is still manual so as to keep } \\
\text { the quality of the products produced }\end{array}$ & by 0.09 & 4 & 0,37 \\
\hline 6 & $\begin{array}{l}\text { Security environment the location of the development AUK can ensure } \\
\text { business continuity }\end{array}$ & of 0.09 & 4 & 0,37 \\
\hline \multirow[t]{3}{*}{7} & consumer Confidence in the products produced & by 0.09 & 4 & 0,37 \\
\hline & Total $(O)$ & Of 0.63 & & 2,35 \\
\hline & Threats $(T)$ & & & \\
\hline 1 & Game price of competitors that sell products of the same & 0,06 & 2 & 0,12 \\
\hline 2 & Many competitors offering a cheaper price & of 0.09 & 1 & 0,09 \\
\hline 3 & $\begin{array}{l}\text { People of the City of Palopo not many people know about the product- } \\
\text { product that is produced by the Association of TandungBilla }\end{array}$ & 0,06 & 2 & 0,12 \\
\hline 4 & fewer customers during the pandemic & to 0.09 & 2 & 0,18 \\
\hline \multirow[t]{3}{*}{5} & the Process of packaging the product-the product produced is still simple & to 0.06 & 2 & 0,18 \\
\hline & $\operatorname{Total}(T)$ & $\mathbf{0 , 3 7}$ & & 0,65 \\
\hline & $\operatorname{Total}(O-T)$ & Of 1.0 & & 1,71 \\
\hline
\end{tabular}

Table 3 matrix of External Factors Analysis Summary (EFAS) the development of a variety of business forestry in Forest farmer groupCommunity forestTandungBilla can be in the know that factors external opportunity (opportunities) from the result of the multiplication of the weight $\mathrm{x}$ rating is 2.35 , and the factors of threats (threat) are 0,65 . So the total option minus threats $(O-T)$ is 1,71 .

SWOT analysis (EFAS) that has been done shows that the odds tend to be larger than the challenge. This is due to the public, or members of farmer groups have been many who are interested in developing a variety of forestry businesses through the government's program of Community Forest (Community forest). In addition, the Association of TandungBilla also has been cooperating with business partners in terms of funding and marketing of products.

Human resources (HR) Forest farmer groupTandungBilla has been following the training or training on the development and management of non-Timber Forest products, especially honey bees and rattan. So it is expected that the result of a variety of forestry businesses in TandungBilla can be arranged and well managed.

Game price of competitors who offer lower prices is a challenge for developing a variety of forestry businesses Forest farmer groupTandungBilla. This because the products offered by the Association of TandungBilla is a product that is original quality and although the packaging process is still simple. In addition, in the City of Palopo, not many people know about the product-product that the Association of TandungBilla produces. Therefore the need to expand market share and increase the promotion.

The impact of the pandemic is also significantly affecting the customer. Nevertheless, despite the declining customer, but does not apply to customers of honey. In this pandemic, demand for honey has increased so that 
the chairman of the Association of TandungBilla focuses on managing honey bees managed by KUPS Apiculture Lambanan.

The results of processing the SWOT analysis of IFAS and EFAS then obtained a score of IFAS equal to 2.03 and a score of EFAS by 1.71. Then, the diagram SWOT analysis of the development of a variety of forestry businesses in Forest farmer groupCommunity forestTandungBilla can be seen in figure 1.

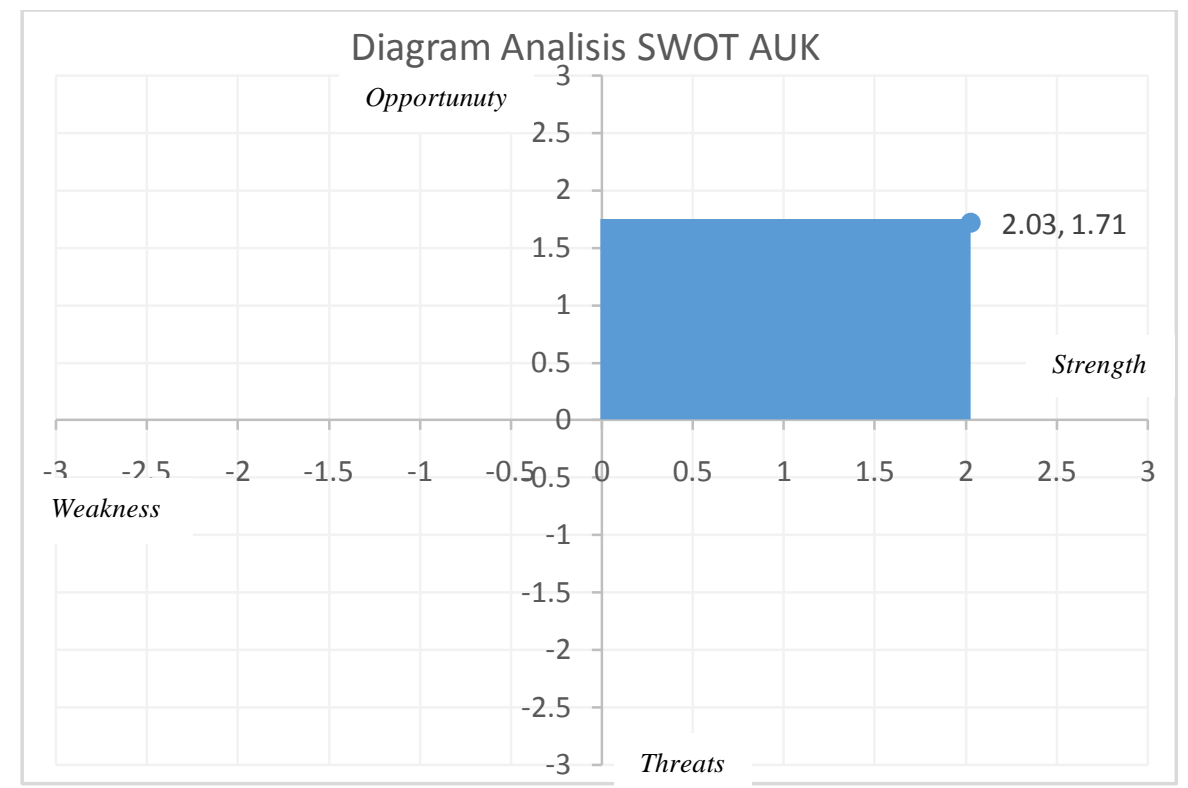

Figure 1. Diagram SWOT Analysis AUK Forest farmer groupCommunity forestTandungBilla

SWOT Diagram (IFAS and EFAS) shows that the strategy of development of Various Forestry Business Forest farmer groupCommunity forestTandungBilla is in quadrant 1 (one) is a strategy S-O (strength opportunity), which means it has an aggressive approach (positive - positive). The value of IFAS, namely 2,03 more inclined to the power (positive) and the value of EFAS that is 1,71, is also more likely to opportunities (positive). Thus, the development of the Various Efforts of Forestry makes it possible to continue to perform the activities of management, development, and add to the production of AUK in Forest farmer groupCommunity forestTandungBilla. The pattern of utilization of its by commodity AUK very potentially to do in the area that the majority of the population in the surrounding very depending on the forest in the forest area belongs to the land has not been utilized optimally. The development of commodity AUK can improve income communities significantly and at the same time rehabilitate degraded land. The result of commodity AUK was directed on the commodity mainstay of the local according to the conditions of the biophysical region, mastery technology, and the culture of the people of the local [1].

Identification of the SWOT analysis (IFAS and EFAS) provides an overview that by making the market segmentation that applies the system, the open market will get more customers. In addition, creating a cooperation agreement between producers (farmers) and partners is expected to strengthen the relationship with customers. Increasing the value to meet the quality standards will further add value and added value. Application of technology of management of various forestry businesses exceptionally NTFP will be the main activity for the producers (farmers). Addition and cooperation with business partners are expected to facilitate and expand the market network for members of farmer groups [14].

The formulation of the development strategy of various forestry businesses can be done by identifying the internal and external factors in the worksheet SWOT matrix as in figure 2. 


\begin{tabular}{|c|c|c|}
\hline EFAS & $\begin{array}{l}\text { Strength (S) } \\
\text { 1. Products NTFPS become a source of } \\
\text { livelihood for the members of the } \\
\text { Association of Community } \\
\text { forestTandungBilla } \\
\text { 2. Quality Products NTFPS Forest farmer } \\
\text { groupCommunity forestTandungBilla } \\
\text { assured } \\
\text { 3. the Products offered is. but care less. } \\
\text { 4. the Price offered is affordable by all } \\
\text { people } \\
\text { 5. Provide economic impact that was good } \\
\text { enough for members of the KTH } \\
\text { TandungBilla } \\
\text { 6. the Results of production can be sold } \\
\text { retail and wholesale } \\
\text { 7. business Development of forestry with a } \\
\text { pattern of Agroforestry effect with the } \\
\text { crop } \\
\text { 8. Development AUK by utilizing NTFPS } \\
\text { good impact on the sustainability of } \\
\text { forest ecosystems }\end{array}$ & $\begin{array}{l}\text { Weakness }(\mathbf{W}) \\
\text { 1. The City government less support } \\
\text { activities Community } \\
\text { forestTndungBilla } \\
\text { 2. In developing AUK requires } \\
\text { considerable cost } \\
\text { 3. management System management } \\
\text { / bookkeeping still less } \\
\text { 4. Mastery of technology } \\
\text { management, the result is still low } \\
\text { 5. Promotion for product-product } \\
\text { that is produced is still less reach } \\
\text { consumers } \\
\text { 6. Outlets or branch to market the } \\
\text { products of the production is still } \\
\text { less }\end{array}$ \\
\hline $\begin{array}{l}\text { Opportunities (O) } \\
\text { 1. Many members of the Association of } \\
\text { TandungBilla who has an interest to } \\
\text { develope AUK } \\
\text { 2. Establish good cooperation with our } \\
\text { business partners } \\
\text { 3. To Expand market share to market } \\
\text { the results of the production of } \\
\text { 4. the Members of the KTH } \\
\text { TandungBilla've been following the } \\
\text { training/training about management } \\
\text { NTFPS } \\
\text { 5. Tool used for producing crops is still } \\
\text { manual so as to keep the quality of } \\
\text { the resulting product } \\
\text { 6. Security environment the location of } \\
\text { the development AUK can ensure } \\
\text { the continuity of the business } \\
\text { 7. consumer Confidence in the products } \\
\text { produced }\end{array}$ & $\begin{array}{l}\text { Strategies S - O } \\
\text { 1. Increase production and the quality of } \\
\text { the AUK (S1,S2,S3,S5,O1,O5,O7). } \\
\text { 2. Increase sales and expand marketing } \\
\text { AUK (S4,S6,O2,O3) } \\
\text { 3. Maintaining the sustainability of forest } \\
\text { ecosystems (S7,S8,O6). } \\
\text { 4. Increase the confidence of consumers } \\
\text { towards products produced } \\
\text { (S2,S3,S4,O7) }\end{array}$ & $\begin{array}{l}\text { Strategy W - O } \\
\text { 1. In Collaboration with our } \\
\text { business partners to market and } \\
\text { promote products AUK } \\
\text { (W5,W6,O2.O3,O7) } \\
\text { 2. Establish cooperation with } \\
\text { investors and business partners } \\
\text { (W2,W4,O2,O4) } \\
\text { 3. Forming branches or outlets to } \\
\text { market the products AUK to the } \\
\text { trust of consumers towards the } \\
\text { products offered is increasing } \\
\text { (W5,W6,O3,O7). }\end{array}$ \\
\hline $\begin{array}{l}\text { Threats (T) } \\
\text { 1. The Game the price of competitors } \\
\text { that sell products of the same } \\
\text { 2. Lot of Competitors who offer } \\
\text { cheaper prices } \\
\text { 3. People of the City of Palopo not } \\
\text { many people know about the } \\
\text { product-product that is produced by } \\
\text { the Association of TandungBilla } \\
\text { 4. Fewer customers during the } \\
\text { pandemic } \\
\text { 5. The Process of packaging the } \\
\text { product-the product produced is still } \\
\text { simple }\end{array}$ & $\begin{array}{l}\text { Strategy S - T } \\
\text { 1. Improve product quality-roduct AUK } \\
\text { and the quality of service to consumers } \\
(\mathrm{S} 1, \mathrm{~S} 2, \mathrm{~S} 3, \mathrm{~T} 2, \mathrm{~T} 3, \mathrm{~T} 4) \\
\text { 2. Set the strategy the price of the products } \\
\text { AUK (S4,S6,T1) } \\
\text { 3. Improve the quality of work members } \\
\text { of the KTH Forest farmer } \\
\text { groupCommunity forestTandungBilla } \\
\text { become better (S7,T5). }\end{array}$ & $\begin{array}{l}\text { Strategy W - T } \\
\text { 1. Pay More attention to the quality } \\
\text { of the products AUK and the } \\
\text { quality of service to consumers } \\
\text { (W4,W5,W6,T1,T2,T3,T4,T5) } \\
\text { 2. Expand networks to introduce and } \\
\text { market products AUK } \\
\text { (W5,W6,T3,T4). }\end{array}$ \\
\hline
\end{tabular}

\section{Figure 2. SWOT matrix strategies development AUK Forest farmer groupCommunity forest TandungBilla}

Figure 2 SWOT matrix strategies the development of a variety of forestry businesses Forest farmer groupCommunity forest Tandung Billa can be formulated several strategies where the strategy S-O can produce a design that uses force to take advantage of opportunities. Increasing the production and quality of the various forestry efforts can gradually improve sales and expand marketing. In addition,an increased rate can increase consumer confidence in the products produced, and the development potential of NTFPS can maintain the sustainability of forest ecosystems. 
Strategy S-T where this strategy produces a strategy that uses force to overcome the threat. Game price of competitors that sell products similar with a lower price is a threat in developing various forestry businesses. It needs to define a strategy to determine the prices and improve the quality of service to consumers.

Strategies W-O strategy that minimizes the power to take advantage of opportunities. A method was formulated that work together with our business partners to market products produced and establish good cooperation with investors in terms of funding for the development of a variety of forestry business.

The latter strategy is the strategy W-T is a strategy that minimizes weaknesses and avoids threats. Lack of support from the Government of the City of Palopo is one of the weaknesses in the management of Community forestTandungBilla. People of the City of Palopo, not many people know about the products produced by the farmer group TandungBilla members. Therefore, further expanding the network to introduce and market the effects of various forestry businesses made.

Success identifies the internal and external factors from the outset will facilitate an organization to maximize all the potential to realize the program of work and anticipate possible problems faced in the future. Readiness in handling this issue is necessary to minimize the risk of failure of implementation of programs and activities. Good planning is based on a sound strategy anyway, so the formulation of the design is essential precedence [15]

According to [13], one of the strategies of development of NTFPS that support of the government and the relevant agencies is essential in the development of the potential of NTFPS start of the permitting process IUPCommunity forest so that it can perform cooperation in the form of counseling, training to the provision of quality raw materials. These activities can increase the creativity of members of farmer groups in land use, and business development that is more diverse is expected to increase the income of members of farmer groups.

For the community that the level of dependence on the forest is very high, the development of commodity AUK can reduce the pressure of society toa forest area that ada better form of encroachment of the forest (land encroachment) even illegal logging. The current development of the last day's AUK by the community has experienced a shift of that nature of subsistence into commercial thoughl by considering loss andthe prospects of the market. The developing commodity AUK isdone at the forest area aims to optimize the space to grow and increase the income of the community as well as at once to rehabilitate degraded land/less productive that number is in Indonesia is estimated at $41 \%$ of the total forest area in Indonesia or around 77,8 million hectares [16].

\section{CONCLUSION}

The conclusion of this research is based on two factors, namely internal and external factors. Internal Factor Analysis Summary (IFAS) development of various forestry businesses in Forest farmer groupCommunity forest Tandung Billa obtained that the internal factors in the form of strength are 2,58 and factors weaknesses is 0.55. So the total strength minus weakness ( $-\mathrm{W}$ ) is 2,03. While the External Factor Analysis Summary (EFAS) development of various forestry businesses in Forest farmer group Community forest Tandung Billa obtained that factors external opportunity is 2,35 , and the characteristics of threats are 0.65 . So the real opportunity minus threats $(\mathrm{O}-\mathrm{T})$ is 1,71 . An alternative strategy that can be used to develop various forestry business in Forest farmer group Community forest Tandung Billa is a Strategy S-O that means it has the strategy of aggressive (positive - positive). The form of the development of production and the quality of analysis of the forestry business in Forest farmer group Community forestTandung Billa such as increasing sales and expanding their market, increasing consumer confidence in the products offered, and maintaining the sustainability of forest ecosystems.

\section{BIBLIOGRAPHY}

[1] S. Suharti, "the Increase in the community's income through the cultivation of commodity a variety of forestry business (AUK)," vol. 1, no. September, things. 1416-1419, 2015, doi: 10.13057/psnmbi/m010626.

[2] A. S. T. D. hari Wijayanto, "Community Development Forest Approximately Planning Through Various Forestry Business (Studies in Malang Regency Forest Service),” J. Forest Trop., vol. 2, no. 1, pg. 8, 2014.

[3] A. Wachid, Tandung Billa Lestari My Woodland Prosperous People. Palopo: Onomastika Production, 2017. 
Forest (Community forest) Against the Income of Farmers in Kulon Progo,” J. Science in the Woods., vol. 12, no. 1, pg. 86, 2018, doi: $10.22146 /$ jik.34123.

[5] M. Muhdar, G. D. Dirawan, and M. Wiharto, "an Overview of Management (Community Forest) Community forest in Indonesia," UNM Environ. Journals, vol. 2, no. 1, pg. 18, 2019, doi: 10.26858/uej.v2i1.9160.

[6] A. Pradana, "marketing Strategy with the use of analysis of s.w.o.t on syafia plaza jember," J. Marketers. Univ. Muhammadiyah Jember, no. 3, pg. 1-12, 2015.

[7] B. C. W. Kiagus Ridwan, Rusman Ali, “Analysis of EFAS and IFAS in the Company of Singapore Airlines,” it. 1-31, 2015.

[8] H. Mayrowani and N. Ashari, "the Development of Agroforestry to Support Food security and Empowerment of Farmers Around the Forest," Forum Research. Agro Econ., vol. 29, no. 2, pg. 83, 2016, doi: 10.21082/fae.v29n2.2011.83-98.

[9] Albasri, S. A. Paembonan, S. Millang, and A. ma'ruf, "Design of Agroforestry On Critical Land In the Village of Wood You Kecamatan Bantaeng Bantaeng,” Ecogreen, vol. 1, no. 1, pg. 79-88, 2015.

[10] G. Group, Tani Forests, and G. Tandung Billa, "the Management of the Forest Area Community."

[11] S. Marpaung, A. Dalimunthe, and B. Utomo, "an Inventory of the Plants MPTS ( Multi-Purpose Tree Species ) In the Area Catchment of Lake Toba North Sumatra Province ( MPTS plant inventory in the catchment area of Toba Lake at North Sumatera Province )," it. 1-5, 2014

[12] R. Haryani and R. Rijanta, "People's Dependence On Protected Forest In the Community forestry Programs," J. of $r$ \& $d$ Sukowati Media Research. and Wel., vol. 2, no. 2, pg. 15, 2019, doi: 10.32630/sukowati.v2i2.70.

[13] D. Indrasari, C. Wulandari, and A. Bintoro, "Development of the Potential of non-Timber Forest By a Group of Conscious Sustainable Forest Wana Agung In the Register 22 Way Waya Central Lampung Regency,” J. Sylva Lestari, vol. 5, no. 1, pg. 81, 2017, doi: $10.23960 /$ js11581-91.

[14] Andi Acmad Rizaldy the U.S., Makkarennu, Syahidah "Application of Business Model Canvas Blue Ocean Strategy on the Palm Sugar Business Development,” Int. J. Sci. Manag. Stud., vol. 4, no. 4, pg. 385-396, 2021, doi: 10.51386/25815946/ijsms-v4i4p135.

[15] fmu-protected Unit VIII Latimojong, Long Term Forest Management Plan fmu-protected Unit VIII Latimojong (RPJHP), 1 ed. Luwu, 2019.

[16] L. V work forms et al., "Reducing forestry emissions in Indonesia," Cent. Int. For. Res., it. 1-12, 2010. 